\title{
A MICROAULA COMO INSTRUMENTO DE APRENDIZAGEM DO SER PROFESSOR NO ENSINO DA MÚSICA
}

\section{THE MICROAULA AS A LEARNING INSTRUMENT OF BEING A TEACHER IN TEACHING MUSIC}

\author{
Miguel Pereira dos Santos ${ }^{1}$; Sorane Costa Soares ${ }^{2}$; Daniel Medeiros Rezende ${ }^{3}$; Eraldo Lopes \\ dos Santos ${ }^{4}$; Marina Marcos Costa ${ }^{5}$
}

\section{INTRODUÇÃO}

A atividade a ser relatada ocorreu no âmbito da disciplina Didática Geral do curso de Licenciatura em Música pela Universidade Federal do Piauí - Campus Petrônio Portela, a qual é ministrada pela professora orientadora lotada no Departamento de Métodos e Técnicas de Ensino no Centro de Ciências em Educação. A disciplina possui a finalidade de expor os Fundamentos epistemológicos da Didática; A didática e a formação do professor; $\mathrm{O}$ planejamento didático e a organização do trabalho docente.

A fim de que se consiga aprender conteúdos e desenvolver habilidades e competências que tornem o licenciando em um profissional do ensino de música, para Schön (1983) é necessário que esse aprenda a ser reflexivo, dinâmico e crítico sobre as suas atitudes e a comunidade na qual está inserido para haver a transformação de sua prática. É preciso a associação entre o conhecimento teórico relacionado à educaçãobrasileira de maneira geral e prático, especificamente, na música.

Partindo-se disso, verifica-se a importância das competências apreendidas e exploradas durante o curso Técnico em Instrumento Musical - Saxofone, promovido pelo Instituto Federal de Educação, Ciência e Tecnologia do Piauí - Campus Teresina Central, em vista da contribuição teórica e prática obtida no curso. É válido ressaltar que o foco deste relato se refere a experiência de pesquisa e aprendizagem de conhecimentos teóricos da disciplina mencionada ministrada no $3^{\circ}$ período, identificada como da “área” pedagógica.

\footnotetext{
${ }^{1}$ Licenciatura em Música e Técnico em Instrumento Musical - Saxofone, Universidade Federal do Piauí e Instituto Federal de Educação Ciências e Tecnologia do Piaúi - Campus Teresina Central, nim.nik.nix@gmail.com

${ }^{2}$ Licenciatura em Música, Universidade Federal do Piauí, soranecosta@ hotmail.com

${ }^{3}$ Licenciatura em Música, Universidade Federal do Piauí, danielbateram@gmail.com

${ }^{4}$ Especialista, Instituto Federal de Educação Ciências e Tecnologia do Piauí - Campus Teresina Central, eraldo@ifpi.ebu.br

${ }^{5}$ Mestre, Universidade Federal do Piauí, marina.mcosta@ hotmail.com
} 
Dessa forma, este estudo tem como objetivo relatar a experiência com a microaula como instrumento de aprendizagem do ser professor para o ensino de Música por meio da disciplina de Didática Geral. Acredita-se que este estudo é relevante considerando o momento da microaula como essencial no aprendizado do ser professor na prática do uso das metodologias, dos recursos, na construção de objetivos, na seleção de conteúdos, na organização do tempo da aula, e na formulação de dinâmicas e atividades avaliativas que a disciplina Didática visa sistematizar. Nesse sentido, como discente foi possível sistematizar os conteúdos da área de Música em uma microaula voltada para o âmbito escolar.

\section{RELATO DE EXPERIÊNCIA}

$\mathrm{Na}$ formação dos profissionais da área da educação, é de fundamental importância o desenvolvimento da prática, promovendo uma experiência para auxiliar na atuação profissional de um professor. A disciplina de Didática Geral, ministrada no $3^{\circ}$ período do curso de Licenciatura em Música da Universidade Federal do Piauí, propôs a microaula com o intuito de preparar os discentes do curso, a que referido, por meio da contextualização do aprendizado referente à didática da ementa da disciplina, assim como também, para que construam uma postura profissional qualificada.

É afirmado na Lei de Diretrizes e Bases da Educação Nacional (LDBEN) 9.394/1996 acerca das sugestões nos currículos e aborda o tema da contextualização na educação, e continua dizendo que

[...] é na dinâmica de contextualização/descontextualização que o aluno constrói conhecimento com significado, nisso se identificando com as situações que lhe são apresentadas, seja em seu contexto escolar, seja no exercício de sua plena cidadania. A contextualização não pode ser feita de maneira ingênua, visto que ela será fundamental para as aprendizagens a serem realizadas - o professor precisa antecipar os conteúdos que são objetos de aprendizagem. Em outras palavras, a contextualização aparece não como uma forma de "ilustrar" o enunciado de um problema, mas como uma maneira de dar sentido ao conhecimento matemático na escola. (BRASIL, 2006, p. 83)

Para a execução do trabalho, a princípio, foram recebidas as orientações da professora orientadora da disciplina acerca da elaboração de uma microaula, com base em todo o conteúdo didático já estudado no âmbito da disciplina e, em seguida, os estudantes foram divididos em grupos onde, no que participei, decidiu-se abordar a apresentação sobre os aspectos do aprendizado em música, focando no ensino dos instrumentos de percussão com o auxílio da tablatura e o ensino da forma cânone. . Inicialmente, foi sistematizada, através do plano de aula, toda a proposta a ser trabalhada em microaula. Após definido o conteúdo a ser abordado, se definiu o tempo para a execução de cada ponto a ser feito a seguir. Em seguida, 
foi estabelecida a relação de quais recursos didáticos seriam utilizados e atividades fixadoras ao final das apresentações para consolidar o aprendizado dos discentes. É importante pontuar que o estabelecimento do plano de aula foi de fundamental importância para sistematizar e organizar todo o resto dos conteúdos e sua aplicação.

No segundo momento, apresentou-se uma série de instrumentos percussivos distintos, juntamente com uma demonstração do timbre de cada um. Cada instrumento foi associado com uma letra, e, em seguida, foram expressas, em um quadro, várias sequências de letras simultâneas e consecutivas - formando frases musicais, já que cada letra, associada a um instrumento, significava uma batida nesse respectivo instrumento. Por meio dessa atividade foi possível fazer com que até os discentes com um conhecimento mínimo de percussão pudessem tocar os instrumentos de forma eficiente e .

Seashore (apud FONTERRADA, 2001, p.80), acerca da prática rítmica e da percepção auditiva, afirma que

As impressões de ritmos musicais despertam sempre, e em certa medida, imagens motoras na mente do ouvinte, e em seu corpo, reações musculares intuitivas. As sensações musculares acabam por associar-se às sensações auditivas que, assim reforçadas, se impõem mais ao espírito, para apreciação e análise. (apud FONTERRADA, 2001, p.80)

Posteriormente, no segundo momento da micro aula, foi exposta uma música através de caixa de som para assimilação dos discentes. A música foi repetida até que se percebesse o que estava a ocorrer com a sua forma. Notou-se que a música possuía duas linhas melódicas distintas sendo cantadas ao mesmo tempo. Depois dessa percepção, ficou clara a lógica usada na elaboração da forma musical conhecida como cânone.

Cruvinel (2003) ressalta que no contexto contemporâneo acredita-se que através do ensino de música nas escolas

[...] os alunos poderão ter uma educação musical transformadora, onde poderão vivenciar novas experiências tanto no âmbito individual quanto no coletivo. A partir da experiência em grupo, os alunos poderão vivenciar situações e dinâmicas, interagindo e socializando com os demais colegas, contribuindo para que sua formação musical e instrumental seja mais lúdica.

Os estudos sobre os avanços obtidos em décadas acerca do ensino no Brasil e mundial, na formação inicial de licenciatura, se mostra de grande relevância e contribui positivamente para o desenvolvimento crítico do futuro profissional do ensino de música, uma vez que, esses discentes, terão mais propriedade e domínio sobre os aspectos históricos que contribuíram para as metodologias, habilidades e didáticas aplicadas, principalmente, no ensino da música para os estudantes da Educação Básica. 


\section{CONSIDERAÇÕES}

Haja vista que, para a formação de um profissional de educação é preciso, além do conhecimento teórico, o conhecimento prático como por exemplo as técnicas necessárias para ser desenvolvido um profissional qualificado, percebe-se que, embora instituições distintas e com diferentes cursos na mesma área, em ambos, UFPI e IFPI, o objetivo e comprometimento com a educação de seus estudantes se fazem presentes, com igual eficiência e relevância para a formação profissional dos mesmos. O processo de aprendizado adquirido nessas instituições contribui positivamente para a formação de profissionais motivados para mudar a educação nacional.

A atividade foi uma experiência muito proveitosa e positiva para minha formação em diversos aspectos, devido ao êxito de sua proposta de proporcionar ao licenciando uma experiência real do exercer de sua futura profissão. Seria de essencial importância se ocorressem por mais vezes atividades com este mesmo intuito.

\section{REFERÊNCIAS}

BRASIL. Lei n ${ }^{\circ}$ 9.394, de 20 de dezembro de 1996. Diretrizes e Bases da Educação Nacional. Brasília, DF. 1996

CRUVINEL, F. M. Efeitos do Ensino Coletivo na Iniciação Instrumental de Cordas: A educação musical como meio de transformação social. Goiânia, Dissertação de mestrado Escola de música e artes cênicas, Universidade Federal de Goiás, 2003.

FONTERRADA, M.T.O. De tramas e fios: um ensaio sobre música e educação. São Paulo, 2001.(Tese - Livre-Docência - Instituto de Artes da Universidade "Júlio de Mesquita Filho").

SCHÖN, D. A. O Profissional Reflexivo: como os profissionais pensam em ação. Londres: TempleSmith, 1983. 